\title{
Affordable Housing Performance Indicators for Landed Houses in the Central Region of Malaysia
}

\author{
Ahlam M. Jamal Eshruq Labin ${ }^{1}$, Adi Irfan Che-Ani ${ }^{1} \&$ Syahrul Nizam Kamaruzzaman ${ }^{2}$ \\ ${ }^{1}$ Department of Architecture, Faculty of Engineering \& Built Environment, Universiti Kebangsaan Malaysia \\ (UKM), 43600 UKM Bangi, Selangor, Malaysia \\ ${ }^{2}$ Department of Building Surveying, Faculty of Built Environment, University of Malaya, 50603 Kuala Lumpur, \\ Malaysia \\ Correspondence: Ahlam M. Jamal Eshruq Labin, Department of Architecture, Faculty of Engineering \& Built \\ Environment, Universiti Kebangsaan Malaysia (UKM), 43600 UKM Bangi, Selangor, Malaysia. Tel: \\ 962-789-494-101. E-mail: ahlam.laban@yahoo.com
}

Received: July 7, $2014 \quad$ Accepted: August 8, $2014 \quad$ Online Published: September 12, 2014

doi:10.5539/mas.v8n6p70 URL: http://dx.doi.org/10.5539/mas.v8n6p70

\begin{abstract}
Recently, governments strive to make housing affordable for residents. Affordable housing is not restricted only to the house prices, but it includes also the quality and amenities of the house. So, the main aim of this research is to develop affordable housing performance indicators (AHPI) for landed houses. It's based mainly on Mulliner and Malienes criteria for affordable housing and the concept of grow home for Friedman and Cammalleri. Taman Selasih (TS) and Taman Lukut Makmur (TLM) in Negeri Sembilan were chosen as a case study. They were constructed by Syarikat Perumahan Negara Berhad (SPNB) in the central region of Malaysia. The sample consists of 155 units in TS and 93 units in TLM. A physical survey was conducted to assess the housing affordability for TS and TLM by field observation and informal interviews with the residents. The collected data were analyzed via SPSS software. The result shows that fourteen criteria can be applied as AHPI for landed houses, namely; houses prices in relation to income, safety- incidence of crime, access to employment, access to public transport facilities, access to good quality schools, access to shopping facilities, access to health care, access to child care, access to leisure facilities, access to open green public space, quality of housing, energy efficiency, land properties and new spaces. The value of this research comes from proposing a set of criteria that could be used as affordable housing performance indicators (AHPI) to assess the performance of landed houses.
\end{abstract}

Keywords: affordable housing, affordable housing performance indicators, building performance, PR1MA

\section{Introduction}

A house is one of the basic human needs; most daily life practices of people occur at home. To satisfy the human need for a home, a diverse range of concepts has risen to make housing more affordable to families and individuals; and one such concept has 'grow home'. Grow home aims to build houses for sale, which can be afforded by low-income families (Friedman \& Cammalleri, 1994).

Affordability concerns to make the housing affordable for every household. It is not meant low prices; it needs a lot of work to give a good quality (Kim et al., 2004). Housing affordability is a feature of housing and housing service in relation to consumer ability and desire to own or buy the houses (Yang \& Shen, 2008).

The concepts of this study emerged from an exploration of published literature, previous research, and involvement in civic activities focused on affordable housing in Malaysia. The study is designed to develop affordable housing performance indicators (AHPI) for landed housing in the central region of Malaysia.

PR1MA (Perumahan Rakyat 1 Malaysia- My First Home Scheme) and SPNB have constructed affordable housing projects in Malaysia. Perumahan Rakyat 1 Malaysia act 2012 is an act to promote the development and construction of PR1MA program in urban Malaysia area to create a strategic socioeconomic housing development model. PR1MA not just a house, it contains amenities, utilities and infrastructure as educational, recreational and clinical facilities (Malaysia act, 2012). 


\subsection{Affordable Housing}

Housing affordability could be defined as a link between housing and people; it is a selection judgment function which is made by a family between housing and non-housing product expenditure (Stone, 2006; Yang \& Shen, 2008; Tawil et al., 2011).

Housing affordability is a tenure-neutral term that denotes the relationship between household income and household expenditure on housing costs. It recognizes the needs of households whose incomes are not sufficient to allow them to access appropriate housing in the market without assistance (Milligan et al., 2004). Thus, the term 'affordable housing' describes housing that assists lower income households in obtaining and paying for appropriate housing without experiencing undue financial hardship (Milligan et al., 2004).

Zhang (2007) and Zhou et al. (2010) employed price-income-ratio (PIR) to indicate the housing affordability where affordability can be defined as a relationship between household income and household expenditure, when the ratio of expenditure to income is reasonable that is the housing affordability (Kuang \& Li, 2012).

Affordable housing doesn't mean only the best price of a house, but also interests in achieving amenities and facilities in low cost areas, so that a wider socioeconomic range of households will choose to locate there (Burke, 2004). National Research Venture (NRV) is important as it seeks to view affordability in terms of economic criteria, in addition to a wider range of quantitative and qualitative criteria that affect a household's quality of life. It also offered a criteria system representing sustainable affordable housing includes; housing, jobs, shops, services, transport and green spaces are important factors for forming successful communities (ODPM, 2005; Fisher et al., 2009).

\subsection{Affordable Housing Performance}

In the past, the stockholders evaluated building performance in an informal manner, and the lessons educated were applied in the next building. This is totally changed today, increasing numbers of technical code and regulatory requirements is employed in services, such as handicapped accessibility, energy conservation, hazardous waste disposal, fire safety, occupational health and safety requirements (Leaman \& Bordass, 2001).

A number of expressions have the same meaning of Building Performance Evaluation as International Building Performance Evaluation (IBPE) (Gibson, 1982; Preiser \& Vischer, 2005), Total Building Performance (TBP), Whole Life Performance, and Overall Performance or Integrated Building Performance (Lützkendorf \& Speer, 2005). Building Performance Evaluation (BPE) can actually change the lives of people and efficiency of organizations that need to conduct measurement; for planning, screening, control and diagnosing (Myeda et al., 2011). The Performance approach is the practice of thinking and working in terms of ends rather than means. BPE contains many issues and criteria, which can be categorized as physical, functional, environmental, financial, economical, psychological and social (Gibson, 1982; Kim et al., 2004; Kuang \& Li, 2012).

The housing affordability has been measured by many approaches, such as housing price to income ratio PIR, housing affordability index HAI, monthly mortgage payment to income ratio and residual income approach. A number of variables used to measure affordability, these include: income, housing costs, unit of analysis, the composition of a household, location factors, the time period of housing affordability should apply, non-housing costs, choice of benchmarks, housing adequacy, and Treatment of housing assistance (Gabriel et al., 2005; Whitehead et al., 2009; Milligan, 2003).

Kim et al. (2005) proposed a housing performance measurement model. They noted that the performance on the housing quality of the residential buildings directly related to the residents' satisfaction with their housing. This states the strengths and weakness point of residential buildings to be bought or leased. Their model based on housing environment, housing function, and housing comfort as indicators of building performance. While, Mulliner and Maliene (2011) assessed the housing affordability by using a multiple criteria decision making method. They proposed various criteria about affordable housing evaluation.

Friedman and Cammalleri (1994) adopted the idea of grow home in Canada as an example of housing affordability. The grow home is townhouse covers approximately $92.9 \mathrm{~m}^{2}$ of area, built with a three storeys that is $4.27 \mathrm{~m}$ wide. The grow home originates with a living room, dining room, kitchen, bathroom, and one or two bedrooms on the second floor. The upper levels in grow home are un-partitioned at the time of selling, to give a chance to the home owner completing it according to their financial resources and the family need (Friedman \& Cammalleri, 1994). 


\subsection{Affordable Housing in Malaysia}

In Malaysia, the National Policy on Environment is formulated to ensure the long-term sustainability and improvement in the quality of life. Malaysia's Vision 2020 has stressed on providing enough essential shelters and accessing health facilities and all the basic amenities, which are the bases for improving the quality of life (tan, 2011). Nevertheless, Malaysia owns a local's Quality of Life Index (MQLI). The Malaysia's Quality of Life Index (MQLI) is a composite index based on the indices of the following eleven components (MQOL, 2004): Income and distribution, working life, transport and communications, health, education, housing, environment, family life, social participation, public safety, as well as culture and leisure.

Various types of affordable housing schemes were constructed in Malaysia to satisfy the needs of low-medium and medium income groups, namely; single storey houses, double-storey houses, five-storey apartments, high rise apartment, detached houses and bungalow. The Malaysian Government has defined housing as "basic human needs and one of the important components in urban economy". The Malaysian government has committed billions of Ringgit Malaysia for providing its citizen with adequate, affordable and quality housing. Since the First Malaysia Plan (1966-1970), there is an emergingin the development of affordable housing construction in Malaysia that intentionally acts as an approach to afford good quality housing. There are various types of perceived affordable housing (Table 1) built at different states of Malaysia (Abd Aziz et al., 2010).

Table 1. Location and total units of affordable houses in Malaysia

\begin{tabular}{lccc}
\hline Location & Acres & Total units & Implementation \\
\hline Present 11, Putrajaya & 7.6 & 560 & $3-2011$ \\
Bandar TunRazak, Cheras & 10 & 1,320 & $4-2011$ \\
Cyberjaya & 14.8 & 794 & 2012 \\
Bandar Ainsdale, Seremban & 142 & 2,220 & $4-2011$ \\
Putra Heights, Subang Jaya & 7.4 & 260 & 2012 \\
Seremban Sentra & 37.4 & 3,000 & $2-2012$ \\
Presint 11-2, Putrajaya & 3.0 & 255 & $2-1012$ \\
Presint 5, Putrajaya & 11.8 & 1,062 & $2-2012$ \\
Presint 17-1, Putrajaya & 4.1 & 739 & $4-2013$ \\
Presint 17-2, Putrajaya & 8.21 & 368 & $4-2013$ \\
Presint 19-1, Putrajaya & 10.8 & 970 & $4-2015$ \\
Presint 19-2, Putrajaya & 11.9 & 1,067 & $4-2015$ \\
AraDamansara, Petaling & 4.9 & 560 & $2-1012$ \\
Bandar Bukit Raja, Klang & 102.9 & 2090 & 2014 \\
Elmina East, Shah Alam & 31.2 & 420 & $3-2014$ \\
Presint 19-3, Putrajaya & 9.1 & 823 & $4-2016$ \\
Elmina West, Shah Alam & 620 & 6,300 & $3-2017$ \\
Kota Elmina, Sg. Buloh & 400 & 3,950 & $3-2017$ \\
Lagong Mas, Petaling & 620 & 6,300 & $3-2018$ \\
Sg. Besi, Kuala Lumpur & N/A & 10,000 & In planning \\
Total units & & 43,058 & \\
\hline
\end{tabular}

Source: PR1MA Act, 2012.

The Property Market Report indicated that terraced houses accounted for approximately $57 \%$ of the total Malaysian housing stock in the year 2002 (Kubota et al., 2006). The majority of terraced houses are concentrated in Johor Bahru. Further, more than $50 \%$ of them are single storey (Nugroho et al., 2007).

Affordable housing projects were constructed by the private and governmental companies. PR1MA and SPNB are considered as the biggest affordable housing agencies in Malaysia. The program of the My First Home Scheme (Perumahan Rakyat 1Malaysia or PR1MA), give the young households who earn less than 900 USD monthly a chance to buy a house by obtaining $100 \%$ financing for houses costing between 30,000 USD and 67,000 USD with a 30-year repayment period (Malaysia act, 2012).

PR1MA consists of different types of houses layouts (Table 2) such as: studio units, $1+1$ bedroom apartment, 2/3/4 bedroom apartments, it must be an owner occupied. PR1MA was established under the PR1MA Act 2012 to plan, develop, construct and maintain affordable lifestyle housing for middle-income households in key urban 
centers. Middle-income is defined as a monthly household income, between 760 USD and 2,270 USD (Malaysia act, 2012).

Table 2. PR1MA projects

\begin{tabular}{lcc}
\hline Project name & Location & Housing type \\
\hline PR1MA Inanam & DesaImpian, Inanam, Sabah & Apartment \\
PR1MA BuliSim - Sim 1 & Sabah & Apartment \\
PR1MA BuliSim - Sim 2 & Sabah & Apartment \\
PR1MA AlamDamai & Cheras & Apartment \\
PR1MA SerembanSentral & Seremban City & Apartment \\
PR1MA Penang & Penang & Apartment \\
PR1MA Seremban Utara & Seremban Utara & Double storey houses \\
\hline
\end{tabular}

The National Housing Company SPNB (Syarikat Perumahan Negara Berhad) concentrated on the development of affordable houses in Malaysia through the implementation of the affordable housing program (Rumah Mampu Milik Programme). SPNB constructed the housing projects in six locations in Malaysia are: central region, northern region, southern region, eastern region, Sarawak and Sabah (Table 3). The interest of the research is on the landed houses that were constructed by SPNB in the central region such as; Taman Selasih and Taman Lukut Makmur in Negeri Sembilan.

Table 3. SPNB projects

\begin{tabular}{|c|c|c|c|}
\hline Area & Project name & Location & Housing type \\
\hline \multirow[t]{8}{*}{ Central } & Taman Medan Cahaya (phase 1) & Petalig Jaya, Selangor & Low cost apartment \\
\hline & Taman Medan Cahaya (phase 2) & Petalig Jaya, Selangor & Low cost apartment \\
\hline & Laguna Biru & TasikBiru, Selangor & Apartment \\
\hline & Laguna Biru (Phase 2) & TasikBiru, Selangor & Apartment \\
\hline & Alam PRIMA & $\begin{array}{c}\text { Seksyen22, Shah Alam, } \\
\text { Selangor }\end{array}$ & Apartment \\
\hline & Taman Selasih & Kuala Pilah, Negeri Sembilan & $\begin{array}{c}\text { Single storey terrace } \\
\text { house }\end{array}$ \\
\hline & Seremban Putra & $\begin{array}{l}\text { Sikamat, MukimAmpangan, } \\
\text { Seremban, Negeri Sembilan }\end{array}$ & Apartment \\
\hline & Taman LukutMakmur & Lukut, Negeri Sembilan & $\begin{array}{l}\text { Single and double } \\
\text { storey terrace house }\end{array}$ \\
\hline \multirow[t]{6}{*}{ Northern } & Mutiara Vista & Bandar Jelutong, Pulau Pinang & Apartment \\
\hline & Taman Libungan Indah & Butterworth, Pulau Pinang & $\begin{array}{c}\text { Double storey terrace } \\
\text { house }\end{array}$ \\
\hline & Taman Kulim Utama & Kulim, Kedah & $\begin{array}{l}\text { Single and double } \\
\text { storey terrace house }\end{array}$ \\
\hline & Taman PermaiUtama & Gurun, Kedah & $\begin{array}{l}\text { Single and double } \\
\text { storey terrace house }\end{array}$ \\
\hline & Taman Lahat Indah & Hulu Kinta, Perak & $\begin{array}{l}\text { Bungalow and single } \\
\text { storey terrace house }\end{array}$ \\
\hline & Taman Universiti Jaya & Semeling, Kedah & $\begin{array}{l}\text { Singlestorey terrace } \\
\text { house }\end{array}$ \\
\hline \multirow[t]{6}{*}{ Southern } & Taman LimbonganPermai & Bandar Melaka, Melaka & Double storey house \\
\hline & Taman Seri Hilir & On Lok, Melaka & Single storey house \\
\hline & Taman Seri Asahan & Jasin, Melaka & Single storey house \\
\hline & Taman Sutera Wangi & BatuBerendam, Melaka & $\begin{array}{l}\text { Single and double } \\
\text { storey terrace house }\end{array}$ \\
\hline & Taman Seri Setanggi & JalanTebrau, Johor Bahru, Johor & $\begin{array}{l}\text { Apartment and single } \\
\text { storey house }\end{array}$ \\
\hline & Taman Tiara Perdana(Phase 1) & SimpangRenggam, Johor & $\begin{array}{l}\text { Single storey terrace } \\
\text { house }\end{array}$ \\
\hline Eastern & Taman Nusa Puteri & SunaiPuteri, Rompin, Pahang & $\begin{array}{c}\text { Single storey terrace } \\
\text { house }\end{array}$ \\
\hline
\end{tabular}




\begin{tabular}{|c|c|c|}
\hline PerkampunganCeratingDamai & Cherating, Kuantan, Pahang & $\begin{array}{c}\text { Single storey terrace } \\
\text { house }\end{array}$ \\
\hline Taman PulaiIdaman & Temerloh, Pahang & $\begin{array}{c}\text { Single storey terrace } \\
\text { house }\end{array}$ \\
\hline Taman PerisaiWira & Kuala Krai, Kelantan & $\begin{array}{l}\text { Single and double } \\
\text { storey terrace house }\end{array}$ \\
\hline Taman Bator Harmoni & Bachok, Kelantan & $\begin{array}{c}\text { Single storey terrace } \\
\text { house }\end{array}$ \\
\hline Vista Ilmu & Kota Samarahan, Sarawak & Apartment \\
\hline Vista Perdana & Miri, Sarawak & $\begin{array}{c}\text { Single storey terrace } \\
\text { house }\end{array}$ \\
\hline Maju Jaya Apartment & Putatan, Sabah & Apartment \\
\hline Taman LayarImpian & Tuaran & $\begin{array}{c}\text { Single storey terrace } \\
\text { house }\end{array}$ \\
\hline Vista Seri Melalin & Tuaran & $\begin{array}{c}\text { Apartment and single } \\
\text { storey house }\end{array}$ \\
\hline Vista Seri Kiranau & Penampang & Apartment \\
\hline Apartment TuaranImpian & Tuaran & Apartment \\
\hline Vista Minintod & Penampang & Apartment \\
\hline Taman SaujanaKinabalu & Ranau & $\begin{array}{c}\text { Single storey terrace } \\
\text { house }\end{array}$ \\
\hline Taman ApasPermai & Tawau & $\begin{array}{c}\text { Single storey terrace } \\
\text { house }\end{array}$ \\
\hline Putatan Platinum Apartment & Putatan & Apartment \\
\hline
\end{tabular}

Based on the literature review, the study suggests that the performance of the landed houses is affected by several indicators (affordable housing performance indicators). Landed houses in Taman Selasih and Taman Lukut Makmur were tested to determine the affordable housing performance indicators.

\section{Method}

This study based mainly on the literature review to collect the secondary data, and then a physical survey was conducted to assess the housing affordability for Taman Selasih and Taman Lukut Makmur by field observation and informal interviews with the residents at the site. The constructed affordable housing projects in Malaysia were determined by referring to SPNB and PR1MA projects. Then the landed houses (single storey) in the central region were chosen as a case study to be evaluated.

The research has two sample schemes as there are two houses schemes; the first sample represents the houses that were assessed in Taman Selasih and the second sample related to the houses that were assessed in Taman Lukut Makmur. Taman Selasih has 260 houses; all of them are occupied. While Taman Lukut Makmur has 200 houses, 120 houses of them are occupied. Kotrlik and Higgins provided in (2001) table for determining sample size from a given population. Based on Kotrlik and Higgins table of sample size to 260 houses in Taman Selasih the amount of sample size is 155 , while the sample size to 120 houses in Taman Lukut Makmur is 92.

\subsection{Materials and Methods}

Taman Selasih locates in Kuala Pilah in Seremban; it has 260 houses are divided into three housing schemes and prices. And Taman Lukut Makmur locates in Lukut city near Port Dickson in Seremban, it has 200 houses, 120 houses of them are occupied; the houses also are classified into three housing schemes and prices (Table 4).

Table 4. Housing schemes and prices in TS \& TLM

\begin{tabular}{cccc}
\hline \multicolumn{2}{c}{ Taman Selasih } & \multicolumn{2}{c}{ Taman LukutMakmur } \\
\hline House area $\left(\mathrm{M}^{2}\right)$ & House price $(\mathrm{RM})$ & House area $\left(\mathrm{M}^{2}\right)$ & House price $(\mathrm{RM})$ \\
\hline 102.19 & 40000 & 120.77 & 94930 \\
120.77 & 59000 & 132.85 & 106040 \\
130.06 & 75000 & 315.87 & 143410 \\
\hline
\end{tabular}

Various criteria provided by Mulliner and Maliene (2012) and Friedman and Cammalleri (1994) for measuring affordable housing performance were utilized in the research. These criteria were classified into five components are: income ratio, facilities and services, safety and comfort, quality management and grow home. The criteria 
could be considered as affordable housing performance indicators (AHPI).

Variables are divided into dependent variables and independent variables according to their role in the study. Independent variables are affordable housing performance indicators. Independent variable also indicates its impact to other variables (dependent variable). Independent variables (IV) in this study were Mulliner and Maliene criteria and grow home criteria that classified into income ratio, facilities and services, safety and comfort, quality management and grow home. The dependent variable is the variables that described and evaluated as an aim of research. Dependent variable (DV) in this research is affordable housing performance indicators (Table 5).

Table 5. Research variables

\begin{tabular}{lll}
\hline & DV & \\
\hline & Income ratio & House price to income ratio \\
& Facilities and services & Access to employment \\
& & Access to public transport services \\
& & Access to good quality education (school) \\
& & Access to shopping facilities \\
& & Access to health services \\
& & Access to early years child care services \\
& & Access to leisure facilities \\
& & Access to open green public spaces \\
& Safety and comfort & Safety- incidence of crime \\
& Quality management & Quality of housing \\
& & Energy efficiency \\
& Grow Home & Land properties \\
& & New space \\
\hline
\end{tabular}

\section{Criterion 1 (house prices in relation to income)}

This criterion is calculated via dividing the house price by annual household income (Mulliner \& Maliene, 2012; Milligan, 2003). The score band is considered high if the ratio is more than 2.5 , while it is within the average score band if the ratio is 2.5 and it is within the low score band if the ratio is less than 2.5 (Table 11).

\section{Criterion 2 (safety/crime)}

Mulliner and Maliene (2012) assessed this criterion by using the 'crime rate'. For each area the crime rate is calculated by dividing the actual number of crimes by the population and then multiplying by 1000 . In this study, the crime rate for the area of study was obtained from the police station,then the level of crime in an area is compared with the rest of Malaysia to determine the score band.

Table 6. Crime index in Malaysian states (2013-2014)

\begin{tabular}{lcccc}
\hline State & Jan-March 2013 & Jan-March 2014 & $+/-$ & $\%$ \\
\hline Sarawak & 2,397 & 1,831 & -566 & -23.6 \\
Perlis & 255 & 209 & -46 & -18 \\
Pulau Pinang & 2,207 & 1,881 & -326 & -14.8 \\
Melaka & 1,072 & 916 & -156 & -14.6 \\
Johor & 4,300 & 3,776 & -524 & -12.2 \\
Kuala Lumpur & 5,414 & 4,954 & -460 & -8.5 \\
Terengganu & 837 & 766 & -71 & -8.5 \\
Perak & 1,936 & 1,787 & -149 & -7.7 \\
Selangor & 10,336 & 9,711 & -625 & -6 \\
Kedah & 2,157 & 2,079 & -78 & -3.6 \\
Negri Sembilan & 1,513 & 1,527 & 14 & .9 \\
Sabah & 1,320 & 1,334 & 14 & 1.1 \\
Kelantan & 1,340 & 1,373 & 33 & 2.5 \\
Pahang & 1,296 & 1,354 & 58 & 4.5 \\
Malaysia & 36,380 & 33,498 & $-2,882$ & -7.6 \\
\hline
\end{tabular}

Source: Official Portal of Royal Malaysia Police, 2014. 
The crime rate in Negeri Sembilan (the study area) is $.9 \%$ (Table 6), the crime rate is within the high score band if it is less than .9\%, while it is within the average score band if it equals . $9 \%$ and it is within the low score band if the crime rate is more than $9 \%$ (Table 11 ).

\section{Criterion 3 (access to employment)}

This criterion was assessed by measuringthe distance to employment opportunities. It is calculated via maps which show key employment sites and access boundaries (access within 15 minutes, access within 30 minutes). The associated value includes (high, moderate and low) (Mulliner \& Maliene, 2012).

Distance to employment opportunities is classified into three banding scores; high if the access to employment within 15 minutes, average if the access to employment within 30 minutes and low if the access to employment more than30 minutes (Table 11).

\section{Criterion 4 (access to public transport facilities)}

Mulliner and Maliene (2012) assessed access to public transport in two parts; access to bus stops and railway stations. They used three score bands for bus stops are; high if the nearest bus stop within $400 \mathrm{~m}$, average if the nearest bus stop within $800 \mathrm{~m}$ and low if the nearest bus atop over $800 \mathrm{~m}$ away. Meanwhile, the access to the railway station was assessed in three scoring bands; high if the railway locates within $800 \mathrm{~m}$, average if the railway station locates within $1200 \mathrm{~m}$ and low if the railway station locates over $1200 \mathrm{~m}$ away (Table 11).

\section{Criterion 5 (access to good quality schools/education)}

This criterion is assessed for both primary and secondary education by proximity to good quality schools. Accessto good quality schools were divided into three scoring bands are (Table 11); high if the good quality schools within $800 \mathrm{~m}$, average if the good quality schools within $1200 \mathrm{~m}$ and low if the good quality schools over 1200m (Mulliner \& Maliene, 2012).

\section{Criterion 6 (access to shopping facilities)}

This criterion is assessed by determining the distance to local/district center in three scoring bands are; high if the local center within $800 \mathrm{~m}$, average if the local/district center within $1200 \mathrm{~m}$ and low if the local/district center over $1200 \mathrm{~m}$ away (Table 11 ).

\section{Criterion 7 (access to health care)}

Access to health care includes; GPs, pharmacies and hospitals. Thus, for GPs and pharmacies service the scoring band is classified into; high if the amenity locates within $800 \mathrm{~m}$, average if the amenity locates within $1200 \mathrm{~m}$ and low if the amenity locates over $1200 \mathrm{~m}$ away. In the case of hospital, the score band is also classified into; high if the hospital within 30 minutes by public transport, average score band if the hospital within 60 minutes by public transport and low score band if the hospital over 60 minutes by public transport (Table 11).

\section{Criterion 8 (access to child care)}

Access to child care criterion is evaluated via determining the distance between the place of residence and the nearest child care facility. The score band is considered high if the child care facility locates within $600 \mathrm{~m}$, while it is considered within an average score band if the child care facility locates within $1000 \mathrm{~m}$ and the low score band if the child care facility locates over 1000m away (Table 11).

\section{Criterion 9 (access to leisure facilities)}

Access to leisure facilities can be evaluated by determining the distance to both playgrounds/play areas and fitness/leisure centers. Playgrounds/play area was scored in three categories (Table 11); high if the play area within $400 \mathrm{~m}$, average if the play area within $800 \mathrm{~m}$ and low if the play area over $800 \mathrm{~m}$ away. Fitness/leisure centers also were scored in three categories; high if the play area within $1500 \mathrm{~m}$, average if the play area within $2000 \mathrm{~m}$ and low if the play area over 2000m away (Mulliner \& Maliene, 2012).

\section{Criterion 10 (access to open green public space)}

The study assesses this criterion via determining the distance between the place of residence and the nearest open green public spaces. The score band is divided into three levels are; high if the open green public space locates within $400 \mathrm{~m}$, average if the open green public space locates within $800 \mathrm{~m}$ and low if the open green public space locates over $800 \mathrm{~m}$ away (Table 11).

\section{Criterion 11 (quality of housing)}

This study will utilize the code of practice for building inspection (CP BS101) to evaluate the buildings by conducting a building survey. Building condition assessment has three categories are; services, fabric and 
components and site conditions. The quality of the houses is divided into five categories (Table 7); new or as new if the houses just need a minor servicing, fair if the houses need a minor repair, poor if the houses need a major repair or replacement, very poor if the houses are malfunctioning and dilapidated if the houses missing or damage (Che-Ani, 2012).

Table 7. Quality of housing

\begin{tabular}{lcc}
\hline Quality of housing & Associated score & \\
\hline Minor servicing & New/As new & 1 \\
Minor repair & Fair & 2 \\
Major repair/Replacement & Poor & 3 \\
Malfunction & Very poor & 4 \\
Damage/Missing & Dilapidated & 5 \\
\hline
\end{tabular}

Quality of housing describes building condition and analysis in Building Assessment Rating System (BARIS). The condition assessment classified into five groups; 1 for the new or as new houses, 2 for fair houses, 3 for the poor houses, 4 means very poor houses and 5 dilapidated houses. While, the priority includes four categories are; normal, routine, urgent and emergency (Table 8 ).

Table 8. Priority assessments

\begin{tabular}{lcccc}
\hline Scale & \multicolumn{4}{c}{ Priority Assessment } \\
\hline Condition Assessment & E4 & U3 & R2 & N1 \\
\hline 5 & 20 & 15 & 10 & 5 \\
4 & 16 & 12 & 8 & 4 \\
3 & 12 & 9 & 6 & 3 \\
2 & 8 & 6 & 4 & 2 \\
1 & 4 & 3 & 2 & 1 \\
\hline
\end{tabular}

Source: Che-Ani, 2012.

Table 9. Priorities

\begin{tabular}{|c|c|c|}
\hline Priority & Scale value & Description \\
\hline Normal & 1 & Functional $\backslash$ only cosmetic defect \\
\hline Routine & 2 & $\begin{array}{c}\text { Minor defect, but can led to the serious defect if left } \\
\text { unattended }\end{array}$ \\
\hline Urgent & 3 & $\begin{array}{c}\text { Serious defect cannot function to an acceptable } \\
\text { slandered }\end{array}$ \\
\hline Emergency & 4 & $\begin{array}{c}\text { Elementary } \backslash \text { structure not function at all or risk that can } \\
\text { lead to fatality and (or) injury }\end{array}$ \\
\hline
\end{tabular}

Source: Che-Ani, 2012.

The building rating is classified into three score bands; good, fair and dilapidated (Table 10). If the building rating is good, the affordable score band is high, while it is average if the building rating is fair and it is low if the building rating is dilapidated.

Table 10. Overall building rating

\begin{tabular}{lcc}
\hline No & Building rating & Score \\
\hline 1 & Good & $1-4$ \\
2 & Fair & $5-12$ \\
3 & Dilapidated & $13-20$ \\
\hline
\end{tabular}

Source: Che-Ani, 2012. 


\section{Criterion 12 (energy efficiency of housing)}

The amount of annual consumption of electricity in residential buildings in Malaysia is approximately 10 to 25 $\left(\mathrm{kWh} / \mathrm{m}^{2} /\right.$ year) (Jamaludin, 2011; Aun, 2007).Saidur (2009) estimated energy intensity (EI) in $\mathrm{kWh} / \mathrm{m}^{2}$ by using the following equation: $\mathrm{EI}=\mathrm{AEC} / \mathrm{TFA}$ where, AEC is annual energy consumption (kWh) and TFA is the total floor area $\left(\mathrm{m}^{2}\right)$. This equation will be used in this study, to calculate the annual consumption of electricity in residential buildings (ACER).

The score band is classified into three groups; high if the annual consumption is less than $10 \mathrm{kWh} / \mathrm{m}^{2}$. Average score band if the annual consumption of electricity in residential buildings (ACER) of a family (can get from their monthly bills) in the range of $\left(10-25 \mathrm{kWh} / \mathrm{m}^{2}\right)$, and low if it is more than $25\left(\mathrm{kWh} / \mathrm{m}^{2}\right)$ (Table 11).

\section{Criterion 13 (land properties)}

Avi Friedman and Vince Cammalleri (1994) suggested that the cost savings of the grow home are achieved by building it in small lots, thereby reducing land costs. The small lot size and high density, reduce the per unit hard infrastructure costs by $60 \%$ compared to single family houses on regular lots. Small building size reduces the amount of labour needed for construction and the amount of building materials that are needed. This study classified the score band into three groups (Table 11); high if the land properties are small, average score band if the land properties are medium and low if the land properties are large areas (Table 4).

\section{Criterion 14 (new spaces)}

The concept of grow home based on selling a house that has the ability to be added with new spaces to the original plan if there is a need as the family grow (Friedman \& Cammalleri, 1994). This study suggests that the number of new spaces that were added to the houses can be classified into three levels: no new spaces were added after household bought the house, one new space was added and two new spaces were added. The affordable score band classified into; high if two new spaces were added, average if one new space was added and low if no new spaces were added (Table 11).

Table 11. Criteria measurements score band

\begin{tabular}{|c|c|c|c|c|}
\hline & Criteria & Associated scope & & \\
\hline \multirow[t]{3}{*}{1} & House price to income ratio & More than 2.5 & Low & 1 \\
\hline & & 2.5 & Average & 2 \\
\hline & & Less than 2.5 & High & 3 \\
\hline \multirow[t]{3}{*}{2} & Safety/crime & More than .9\% & Low & 1 \\
\hline & & $.9 \%$ & Average & 2 \\
\hline & & Less than $.9 \%$ & High & 3 \\
\hline \multirow[t]{3}{*}{3} & Access to employment & More than 30 minutes & Low & 1 \\
\hline & & Between 15 and 30 minutes & Average & 2 \\
\hline & & Within 15 minutes & High & 3 \\
\hline \multirow[t]{7}{*}{4} & Access to public transport facilities & & & \\
\hline & a- Access to bus stops & More than $800 \mathrm{~m}$ & Low & 1 \\
\hline & & Between $400 \mathrm{~m}$ and $800 \mathrm{~m}$ & Average & 2 \\
\hline & & Less than $400 \mathrm{~m}$ & High & 3 \\
\hline & b- Access to railway station & More than $1200 \mathrm{~m}$ & Low & 1 \\
\hline & & Between $800 \mathrm{~m}$ and $1200 \mathrm{~m}$ & Average & 2 \\
\hline & & Less than $800 \mathrm{~m}$ & High & 3 \\
\hline \multirow[t]{7}{*}{5} & Access to good quality schools & & & \\
\hline & a- Access to primary school & More than $1200 \mathrm{~m}$ & Low & 1 \\
\hline & & Between $800 \mathrm{~m}$ and $1200 \mathrm{~m}$ & Average & 2 \\
\hline & & Less than $800 \mathrm{~m}$ & High & 3 \\
\hline & b- Access to secondary school & More than 2000m & Low & 1 \\
\hline & & Between $1200 \mathrm{~m}$ and $2000 \mathrm{~m}$ & Average & 2 \\
\hline & & Less than 1200 & High & 3 \\
\hline \multirow[t]{3}{*}{6} & Access to shopping facilities & Over $1200 \mathrm{~m}$ & Low & 1 \\
\hline & & Between $800 \mathrm{~m}$ and $1200 \mathrm{~m}$ & Average & 2 \\
\hline & & Less than $800 \mathrm{~m}$ & High & 3 \\
\hline
\end{tabular}


7 Access to health care

a- Access to GPs and pharmacies

b- Access to hospitals

Access to child care

9

Access to leisure facilities

a- Access to play area

b- Access to fitness/leisure

10 Access to open green public space

11 Quality of housing

12 Energy efficiency of housing

13 Land properties

14 New spaces
Over $1200 \mathrm{~m}$

Between $800 \mathrm{~m}$ and $1200 \mathrm{~m}$

Less than $800 \mathrm{~m}$

Over 60 minutes by public transport

Between 30 and 60 minutes by public transport

Less than 30 minutes by public transport

Over $1000 \mathrm{~m}$

Between $600 \mathrm{~m}$ and $1000 \mathrm{~m}$

Less than $600 \mathrm{~m}$

Over $800 \mathrm{~m}$

Between $400 \mathrm{~m}$ and $800 \mathrm{~m}$

Less than $400 \mathrm{~m}$

Over $2000 \mathrm{~m}$

Between $1500 \mathrm{~m}$ and $2000 \mathrm{~m}$

Less than $1500 \mathrm{~m}$

Over $800 \mathrm{~m}$

Between $400 \mathrm{~m}$ and $800 \mathrm{~m}$

Less than $400 \mathrm{~m}$

Dilapidated

Fair

Good

More than $25 \mathrm{kWh} / \mathrm{m}^{2}$

Within $10-25 \mathrm{kWh} / \mathrm{m}^{2}$

Less than $10 \mathrm{kWh} / \mathrm{m}^{2}$

Large area

Medium area

Small area

One new space

Two new spaces

Three new spaces
Low 1

Average 2

High 3

Low 1

Average 2

High 3

Low 1

Average 2

High 3

Low 1

Average 2

High 3

Low 1

Average 2

High 3

Low 1

Average 2

High 3

Low 1

Average 2

High 3

Low 1

Average 2

High 3

Low 1

Average 2

High 3

Low 1

Average 2

High 3

\section{Results}

The fourteen criteria were tested in the case of Taman Selasih and Taman Lukut Makmur. By comparing the results in Taman Selasih with the results in Taman Lukut Makmur; both of them have three grouped of houses' areas and prices. One of the notes that the largest house area in Taman Selasih equals the medium area in Taman Lukut Makmur but the priced is doubled in Taman Lukut Makmur as it is constructed later and the price rises. Also, the medium area houses in Taman Selasih equal the small area houses in Taman Lukut Makmur but the price is doubled in Taman Lukut Makmur.

\subsection{Criterion 1 (House prices in relation to income)}

Average household income increased from RM264 (1970) to RM5000 (2012) (Yusuf, 2013). The majority of households earns between 2000RM and 3999Rm in Taman Selasih and Taman Lukut Makmur, and the minority in both of them earns more than 6000RM, the reasons for that are; most of them work in governmental jobs and most of the families are based on one monthly income source (Table 12).

Table 12. Households income

\begin{tabular}{lcc}
\hline Monthly income & TLM & TS \\
\hline Less than 2000R & $14 \%$ & $7.7 \%$ \\
2000-3999RM & $51.6 \%$ & $69 \%$ \\
4000-5999RM & $26.9 \%$ & $18.7 \%$ \\
More than 6000RM & $7.5 \%$ & $4.5 \%$ \\
\hline
\end{tabular}


Since the monthly household incomes are almost the same in both of Taman Selasih and Taman Lukut Makmur (Table 12), and the house' prices are doubled in Taman Lukut Makmur, already the price to income ratio will double in Taman Lukut Makmur (Table 4).For this criterion a higher score is worse for housing affordability (more than 2.5); in TLM $38.7 \%$ of the sample arewithin the high score band, while $68.5 \%$ of the sample in TS are within the high score band (less than 2.5), where the high score (more than 2.5) is 54.8\% in TLM and it is $7.1 \%$ in TS. So, TS is considered within the high score band while TLM within the low score band (Table 13).

Table 13. The price to income ratio

\begin{tabular}{lcc}
\hline PIR & TLM & TS \\
\hline Less than 2.5 & $38.7 \%$ & $86.5 \%$ \\
2.5 & $6.5 \%$ & $6.5 \%$ \\
More than 2.5 & $54.8 \%$ & $7.1 \%$ \\
\hline
\end{tabular}

\subsection{Criterion 2 (Safety- incidence of crime)}

This criterion was assessed by determining the crime rate in TLM and TS by referring to the police stations and comparing it with the crime rate in Negeri Sembilan (.9\%). The crime rate for Taman Lukut Makmur increased from $.6 \%$ in 2012 to $.7 \%$ in 2013 due to the increase in the residents.

Also, the crime rate in Taman Selasih increased from .7\% to .8\%. Moreover, the crime rate in Taman Selasih is higher than the crime rate in Taman Lukut Makmur as it constructed before Taman Lukut Makmur and the population in TS is more than the population in TLM. But both of them are considered within the high score band as the crime rate is less than $.9 \%$ (Table 14 ).

Table 14. Crime index in TS and TLM

\begin{tabular}{lcc}
\hline & $2012 \%$ & $2013 \%$ \\
\hline TLM & $.6 \%$ & $.7 \%$ \\
TS & $.8 \%$ & $.8 \%$ \\
\hline
\end{tabular}

\subsection{Criterion 3 (access to employment)}

Accessibility can be presented by distance, travel time or cost between workers' residence and job location. The majority of the households in Taman Selasih and Taman Lukut Makmur reach their jobs within 15 to 30 minutes; most of them are working in a governmental job in Putrajaya or Kuala Lampur. The households who work in the District Centre need less than 15 minutes to reach their works. Whereas, the minority works outside the area of study and need more than 30 minutes to reach their jobs.

By comparing the results; $29 \%$ of the sample in TLM within the high score band (access to employment less than 15 minutes), while $20 \%$ of the sample in TS within the high score band. The majority, 62.4\% in TLM and $71 \%$ in TS are within the average score band (access to employment between 15 and 30 minutes) (Table 15). So, TS and TLM in this criterion are within the average score band.

Table 15. Access to employment

\begin{tabular}{lcc}
\hline Distance & TLM & TS \\
\hline Less than 15 minutes & $29 \%$ & $20 \%$ \\
$15-30$ minutes & $62.4 \%$ & $71 \%$ \\
More than 30 minutes & $8.6 \%$ & $9 \%$ \\
\hline
\end{tabular}

\subsection{Criterion 4 (access to public transport facilities)}

Generally, all the households have their own private cars. But both of TS and TLM have a high affordable housing performance in the accessibility to the bus stops, on the other hand, they have a low score band in accessibility to the railway stations; since the nearest railway station to TS and TLM locates in Seremban (Table 16). 
Table 16. Access to public transport facilities

\begin{tabular}{lcc}
\hline & TLM & TS \\
\hline Access to bus stops & 200m -high scoring band & 400 - high scoring band \\
Access to railway stations & 30km-low scoring band & 40km- low scoring band \\
\hline
\end{tabular}

\subsection{Criterion 5 (access to good quality schools/education)}

This criterion was assessed by determining the proximity to good quality schools (primary and secondary). The affordable housing performance for access to primary school in TS and TLM is average as the distance between the area of residence and the school is within $1 \mathrm{~km}$, on the other hand the affordable housing performance for access to secondary school in TS and TLM is high; since the distance between areas of the residence and the secondary school is within $1 \mathrm{~km}$ (Table 17).

Table 17. Access to school

\begin{tabular}{lcc}
\hline & TLM & TS \\
\hline Accessibility primary school & $1 \mathrm{~km}$-average scoring band & $1 \mathrm{~km}$ - average scoring band \\
Accessibility secondary school & $1 \mathrm{~km}$-high scoring band & $1 \mathrm{~km}$-high scoring band \\
\hline
\end{tabular}

\subsection{Criterion 6 (access to shopping facilities)}

Based on the scoring band classification, if the accessibility to the nearest shopping facility (District Centre) between $800 \mathrm{~m}$ and $1200 \mathrm{~m}$, the affordability scoring band is average. In TS and TLM the shopping facilities locate in the District Centre within 1km; that means the houses in TS and TLM are within average score band (Table 18).

Table 18. Access to shopping facilities

\begin{tabular}{lcc}
\hline & TLM & TS \\
\hline Distance & $1000 \mathrm{~m}$ & $1000 \mathrm{~m}$ \\
Scoring band & Average & Average \\
\hline
\end{tabular}

\subsection{Criterion 7 (access to health care)}

The research measured this criterion via determining the distance to GPs, pharmacies and hospitals. In TLM the nearest GPs and pharmacies are within $500 \mathrm{~m}$, so it is within the high score band. The nearest hospital locates within $10 \mathrm{~km}$, so the houses in the TLM are within the high score band as the distance to the nearest hospital is within 30 minutes. In TS the nearest GPs and pharmacies is within $10 \mathrm{~km}$, so it is within the average score band, whereas the nearest hospital is within $5 \mathrm{~km}$ that means the houses in TS are within high affordable score band (Table 19).

Table 19. Access to health care

\begin{tabular}{lcc}
\hline Accessibility & TLM & TS \\
\hline To GPs and pharmacies & $500 \mathrm{~m}$ - high scoring band & $1000 \mathrm{~m}$-average scoring band \\
To hospital & $10 \mathrm{~km}$ - high scoring band & $5 \mathrm{~km}$ - high scoring band \\
\hline
\end{tabular}

\subsection{Criterion 8 (access to child care)}

This criterion was assessed via determining the distance to child care facilities from the area of study. In TLM the nearest child care is within $10 \mathrm{~km}$ whereas the nearest one in TS is less than $400 \mathrm{~m}$ as the child care facility in the site itself (Table 20). Based on the scoring band classification, in TLM the access to child care is within the average score band as the distance between $600 \mathrm{~m}$ to $1000 \mathrm{~m}$. In TS, the access to child care is within the high score band as the distance within $600 \mathrm{~m}$. 
Table 20. Access to child care

\begin{tabular}{lcc}
\hline & TLM & TS \\
\hline Distance & $1000 \mathrm{~m}$ & Less than 400m \\
Scoring band & Average & High \\
\hline
\end{tabular}

\subsection{Criterion 9 (access to leisure facilities)}

This criterion was assessed via determining the distance to leisure facilities as play area and fitness facilities. In TLM and TS the nearest play area is within $400 \mathrm{~m}$, both of the study areas have a play area in the site itself. While the nearest fitness facilities in the case of TS and TLM locate within $1500 \mathrm{~m}$, in The District Centre (Table 21). Based on the scoring band classification, the houses in TLM and TS are within the high score band in the accessibility to play area and fitness criterion.

Table 21. Access to leisure facilities

\begin{tabular}{lcc}
\hline & TLM & TS \\
\hline Access to play area & Less than 400m- high scoring band & Less than 400m- high scoring band \\
Access to fitness & Less than 1500 m- high scoring band & Less than 1500 m- high scoring band \\
\hline
\end{tabular}

\subsection{Criterion 10 (access to open green public space)}

This criterion was assessed via determining the distance to the nearest open green public space. In TLM and TS the nearest open green public space is within $400 \mathrm{~m}$ in the site itself (Table 22). Based on the scoring band classification, both of them are within the high score band in this criterion.

Table 22. Access to open green public space

\begin{tabular}{lcc}
\hline & TLM & TS \\
\hline Distance & Less than $400 \mathrm{~m}$ & Less than $400 \mathrm{~m}$ \\
Scoring band & High & High \\
\hline
\end{tabular}

\subsection{Criterion 11 (quality of housing)}

Both of the TS and TLM were built recently, so most of the houses are new or as new just need minor facilities in the front yard as tiling or ceiling to protect from the sun. While the minority is fair and need just minor repairs as wall and fence paint. New houses present $84.9 \%$ of the sample in TLM and $60 \%$ of the sample in TS, as TS was constructed and occupied before TLM.

Based on the score band classification, if the building rating is new (good), the score band is high, while it is within an average score band if the building rating fair and it is within a low score band if the building rating is dilapidated. So, $84.9 \%$ of the sample in TLM and $60.6 \%$ of the sample in TS are within the high score band. $39.4 \%$ of the sample in TS and $15.1 \%$ of the sample in TLM are within the average score band (Table 23). So, the houses in TS and TLM are within the high score band in this criterion.

Table 23. Quality of houses

\begin{tabular}{lccc}
\hline Housing quality & Score band & TLM & TS \\
\hline Good & High & $84.9 \%$ & $60.6 \%$ \\
Fair & Average & $15.1 \%$ & $39.4 \%$ \\
\hline
\end{tabular}

\subsection{Criterion 12 (energy efficiency of housing)}

The energy efficiency results show that $66.7 \%$ of the sample in TLM and $80 \%$ of the sample in TS consume more than $25\left(\mathrm{kWh} / \mathrm{m}^{2} /\right.$ year). $33.3 \%$ of the sample in TLM, and $20 \%$ of the sample in TS consume between 10 and $25\left(\mathrm{kWh} / \mathrm{m}^{2} /\right.$ year) (Table 24). Based on the score band classification; TLM and TS are within the low score band as the majority of the sample $(66.7 \%$ of the sample in TLM and $80 \%$ of the sample in TS) consume more than $25\left(\mathrm{kWh} / \mathrm{m}^{2} /\right.$ year $)$. 
Table 24. Energy efficiency

\begin{tabular}{lccc}
\hline Consumption & Score band & TLM & TS \\
\hline Less than $10 \mathrm{kWh} / \mathrm{m}^{2} /$ year & High & 0 & 0 \\
$10-25 \mathrm{kWh} / \mathrm{m}^{2} / \mathrm{year}$ & Average & $33.3 \%$ & $20 \%$ \\
More than $25 \mathrm{kWh} / \mathrm{m}^{2} /$ year & Low & $66.7 \%$ & $80 \%$ \\
\hline
\end{tabular}

\subsection{Criterion 13 (land properties)}

This criterion achieves the concept of grow home; cost savings of the grow home are achieved by building it in small lots. TS and TLM have three houses' areas; large, medium and small. By comparing the land properties in TS and TLM; $15.1 \%$ of the sample in TLM within the large area $\left(315.87 \mathrm{~m}^{2}\right)$, while in TS $23.9 \%$ of the sample within the large area $\left(130.06 \mathrm{~m}^{2}\right)$. Whereas, $48.4 \%$ of the sample in TLM has the area of $132.85 \mathrm{~m}^{2}$ which is the medium area and $27.1 \%$ of the sample in TS within the medium area $\left(120.77 \mathrm{~m}^{2}\right)$. The small land properties in TLM constitute $36.6 \%$ of the sample while it constitutes the majority of the sample $49 \%$ in TS (Table 25). Based on the score band classification TLM is within the average score band as the majority $48.4 \%$ of the sample are within a medium area, while TS is within the high score band as the majority $49 \%$ of the sample constitutes a small area.

Table 25. Land properties

\begin{tabular}{lccccc}
\hline Area & Score band & \multicolumn{2}{c}{ TLM } & \multicolumn{2}{c}{ TS } \\
\cline { 3 - 5 } & & Area & $\%$ & Area & $\%$ \\
\hline Large & Low & $315.87 \mathrm{~m}^{2}$ & $15.1 \%$ & 130.06 & $23.9 \%$ \\
Medium & Average & $132.85 \mathrm{~m}^{2}$ & $48.4 \%$ & 120.77 & $27.1 \%$ \\
Small & High & $120.77 \mathrm{~m}^{2}$ & $36.6 \%$ & 102.19 & $49 \%$ \\
\hline
\end{tabular}

\subsection{Criterion 14 (new spaces)}

The concept of grow home based on selling houses that have the ability to be added with new spaces to the original plan if there is a need. The results show that, no any renovation works in $89.2 \%$ of the sample in TLM and $54.2 \%$ of the sample in TS; as it is difficult because it needs an acceptance from the government to precede it While $8.6 \%$ of the sample in TLM and $23.9 \%$ of the sample in TS have on new space that was added to the original plan in the front or back yards as a small kitchen or store area. 2.2\% in TLM and 21.9\% in TS have two new spaces (Table 26).

The houses that have two new spaces are the large house as it has an additional spaces beside the back and front yard; and the percent of the large houses in TS is more than it in TLM, consequently the percent of the houses that have two new spaces will be more at TS. Based on the score band classification; $89.2 \%$ of the sample in TLM and $54.2 \%$ of the sample in TS are within the low score band, while $8.6 \%$ of the sample in TLM and $23.9 \%$ of the sample in TS are within the average score band and the high score band constitutes $2.2 \%$ of the sample in TLM and $21.9 \%$ of the sample in TS (Table 26). So, for this criterion both of TS and TLM have a low score band. Table 27 summarizes the criteria score band of TS and TLM.

Table 26. New spaces

\begin{tabular}{lccc}
\hline & Score band & TLM & TS \\
\hline No new spaces & Low & $89.2 \%$ & $54.2 \%$ \\
One new space & Average & $8.6 \%$ & $23.9 \%$ \\
Two new spaces & High & $2.2 \%$ & $21.9 \%$ \\
\hline
\end{tabular}

Table 27. Criteria score band in TS and TLM

\begin{tabular}{llcccc}
\hline & \multicolumn{2}{c}{ Criteria } & \multicolumn{2}{c}{ TLM } & \multicolumn{2}{c}{ TS } \\
\cline { 2 - 5 } & & Points & Score & Points & Score \\
\hline 1 & House price to income ratio & $\bullet$ & Low & $\bullet \bullet \bullet$ & High \\
2 & Safety/crime & $\bullet \bullet$ & High & $\bullet \bullet \bullet$ & High \\
3 & Access to employment & $\bullet$ & Average & $\bullet \bullet$ & Average \\
\hline
\end{tabular}




\begin{tabular}{|c|c|c|c|c|c|}
\hline \multirow[t]{3}{*}{4} & $\begin{array}{l}\text { Access to public transport } \\
\text { facilities }\end{array}$ & & & & \\
\hline & a- Access to bus stops & $\bullet \bullet \bullet$ & High & $\bullet \bullet \bullet$ & High \\
\hline & b- Access to railway station & - & Low & - & Low \\
\hline \multirow[t]{3}{*}{5} & $\begin{array}{l}\text { Access to good quality } \\
\text { schools }\end{array}$ & & & & \\
\hline & a- Access to primary school & $\bullet \bullet$ & Average & $\bullet \bullet$ & Average \\
\hline & b-Access to secondary school & $\bullet \bullet \bullet$ & High & $\bullet \bullet \bullet$ & High \\
\hline 6 & Access to shopping facilities & $\bullet \bullet$ & Average & $\bullet$ & Average \\
\hline \multirow[t]{3}{*}{7} & Access to health care & & & & \\
\hline & $\begin{array}{l}\text { a-Access to GPs and } \\
\text { pharmacies }\end{array}$ & $\bullet \bullet \bullet$ & High & $\bullet \bullet$ & Average \\
\hline & b- Access to hospitals & $\bullet \bullet \bullet$ & High & $\bullet \bullet \bullet$ & High \\
\hline 8 & Access to child care & $\bullet$ & Average & $\bullet \bullet \bullet$ & High \\
\hline \multirow[t]{3}{*}{9} & Access to leisure facilities & & & & \\
\hline & a- Access to play area & $\bullet \bullet \bullet$ & High & $\bullet \bullet \bullet$ & High \\
\hline & b- Access to fitness/leisure & $\bullet \bullet \bullet$ & High & $\bullet \bullet \bullet$ & High \\
\hline 10 & $\begin{array}{l}\text { Access to open green public } \\
\text { space }\end{array}$ & $\bullet \bullet \bullet$ & High & $\bullet \bullet \bullet$ & High \\
\hline 11 & Quality of housing & $\bullet \bullet \bullet$ & High & $\bullet \bullet \bullet$ & High \\
\hline 12 & Energy efficiency & • & Low & • & Low \\
\hline 13 & Land properties & $\bullet \bullet$ & Average & $\bullet \bullet \bullet$ & High \\
\hline \multirow[t]{2}{*}{14} & New spaces & - & Low & • & Low \\
\hline & Total Score & 41 & 2.28 (average) & 44 & 2.44 (average) \\
\hline
\end{tabular}

Based on the previous table; if the score band of affordable housing indicator is high, it has three points. While if it is average, it has two points and if it is low this means one point. Then, the overall points were calculated to state the affordable housing performance for each site. As a result, TS has forty four points $(2.44$, average score band) while TLM has forty one points (2.28 average score band).

Affordable housing performance indicators in TS and TLM are within the average score band for various reasons; the access to the railway station is within a low score band as the nearest one locates in Seremban, energy efficiency also is within the low score band that means the households spend more than $25 \mathrm{kWh} / \mathrm{m}^{2} /$ year which is the determined amount of annual consumption of electricity in residential buildings in Malaysia. And the new spaces that were added to the houses are within the low score band as that need to get the governmental acceptance. Moreover, there are various criteria, are within the average score band as; access to employment, access to primary school and access to shopping facilities.

\section{Discussion}

The present research explores an evaluation process for landed houses performance, after being occupancy in the central region of Malaysia. To begin the research a set of criteria were developed to evaluate the affordable housing performance for landed houses. Those criteria grouped into five components, namely: income ratio, facilities and services, safety and comfort, quality management and grow home.

This study considered the single storey or landed houses in the central region as a case study; because there is no extensive studies examine this type of buildings; most of the researchers studied the office building or high-rise buildings as cases while the other studied the performance of commercial and office building.

The physical survey was used to collect the data and test the criteria by observation. Observations can provide and reconfirm important information that can support the survey results. The combination of observation and surveys is a key methodological approach for this study to observe how the existing conditions of the residential areas (functional, physical, social and psychological) influence affordable housing performance. Notes and picture taking of the residential areas should be the method of recording observations.

Taman Selasih and Taman Lukut Makmur in Negeri Sembilan were chosen to be the cases for the study; they were constructed by Syarikat Perumahan Negara Berhad (SPNB) in the central region of Malaysia. After the physical survey was conducted, the result shows that both of Taman Selasih and Taman Lukut Makmur are within average affordable housing performance score band for various reasons; the access to the railway station is within a low score band as the nearest one locates in Seremban, energy efficiency also is within a low score 
band that means the households spend more than $25 \mathrm{kWh} / \mathrm{m}^{2} /$ year which is the annual consumption of electricity in residential buildings. And the new spaces that were added to the houses are within the low score band as that need to get the governmental acceptance. Moreover, there are various criteria are within the average score band as; access to employment, access to primary school and access to shopping facilities.

As a result the indicators that affect the affordable housing performance of landed houses are; house prices in relation to income, safety- incidence of crime, access to employment, access to public transport facilities, access to good quality schools/education, access to shopping facilities, access to health care, access to child care, access to leisure facilities, access to open green public space, quality of housing, energy efficiency of housing, land properties and new spaces.

This study is considered to be a base for future works; it could be used to assess the landed houses in different areas as, the south, west and north region in Malaysia. This parameter could be applied internationally, and it can be used to assess the affordable housing performance in various building types as double storey houses, low cost housing (five-storey) and apartments (high rise building). Also, the researchers may develop this model for various building functions as; residential, commercial and educational by adding or removing some indicators commensurate with the needs of the building.

\section{Acknowledgments}

The authors wish to thank participants for participating in this project. This work is part of the Doctorate degree.

\section{References}

Abdul-Aziz, A. R., \& JahnKassim, P. S. (2010). Objectives, success and failure factors of housing public-private partnerships in $\quad$ Malaysia. Habitat International, 35(1), 150-157. http://dx.doi.org/10.1016/j.habitatint.2010.06.005

Burke, T. (2004). Measuring housing affordability. Australian Housing and Urban Research Institute, 50107.

Chi-Ani A. I. (2012). CP BS: 101 Code of Practice for Building Inspection Reports. Building Surveying Division, The Royal Institution of Surveyors Malaysia RISM.

Fisher, L. M., Pollakowski. H. O., \& Zabel, J. (2009). Amenity-Based Housing Affordability Indexes. Real Estate Economics, 37(4), 705-746. http://dx.doi.org/10.1111/j.1540-6229.2009.00261.x

Friedman, A., \& Cammalleri, V. (1994). Evaluation of Affordable Housing Projects Based on the Grow Home Concept, Prepared for CMHC.

Kim, J., \& Kaplan, R. (2004). Physical and psychological factors in sense of community: New Urbanist Kentlands and nearby Orchard Village. Environment and Behavior, 36, 313-340. http://dx.doi.org/10.1177/0013916503260236

Kotrlik, J. W. K. J. W., \& Higgins, C. C. H. C. C. (2001). Organizational research: Determining appropriate sample size in survey research appropriate sample size in survey research. Information technology, learning and performance journal, 19(1), 43.

Kuang, W., \& Li, X. (2012). Does China face a housing affordability issue? Evidence from 35 cities in China. International Journal of Housing Markets and Analysis, 5(3), 272-288.http://dx.doi.org/10.1108/17538271211243607

Laws of Malaysia. (2012). Act 739, PerumahanRakayat 1Malaysia Act 2012.

Leaman, A., \& Bordass, B. (2001). Assessing building performance in use 4: The Probe occupant surveys and their implications. Building Research \& Information, 29(2), 129-143. http://dx.doi.org/10.1080/09613210010008045

Lutzkendorf, T., Speer, T., Szigeti, F., Davis, G., Ie Roux, P., Kato, A., \& Tsunekawa, K. (2005). A comparison of international classification for performance requirements and building performance categories used in evaluation methods, proceedings of the $11^{\text {th }}$ Join CIB International Symposium, Helsinki, Finland.

Milligan, V., Phibbs, P., Fagan K., \& Gurran, N. (2004). A Practical Framework for Expanding Affordable Housing Services in Australia: Learning from Experience, Final Report 61 AHURI, Melbourne. Ministry of Housing and Local Government, 2009 and 2013.

Mulliner, E., \& Maliene, V. (2011). Criteria for sustainable housing affordability". In 8th International Conference Environmental Engineering.

Mulliner, E., \& Maliene, V. (2012). What Attributes Determine Housing Affordability? World Academy of 
Science, Engineering and Technology, 67.

ODPM (Office of the Deputy Prime Minister). (2005). Sustainable communities: Homes for all. London: The Stationary Office.

Preiser, W. F. (2005). Building Performance Assessment from POE to BPE, A Personal Perspective. Architectural Science Review, 48(3), 201-204. http://dx.doi.org/10.3763/asre.2005.4826

Stone, M. E. (2006). What is housing affordability? The case for the residual income approach. Housing policy debate, 17(1), 151-184. http://dx.doi.org/10.1080/10511482.2006.9521564

Tan, T. H. (2011). Sustainability and Housing Provision in Malaysia. Journal of Strategic Innovation and Sustainability, 7(1).

Tawil, N., Suhaida, M., Hamzah, N., Che-Ani, A. I., Basri, H., \& Yuzainee, M. Y. (2011). Housing Affordability: A Conceptual Overview for House Price Index.The $2^{\text {nd }}$ International Building Control Conference. Procedia Engineering, 20, 346-353. http://dx.doi.org/10.1016/j.proeng.2011.11.176

Yang, Z., \& Shen, Y. (2008). The affordability of owner occupied housing in Beijing. Journal of Housing and the Built Environment, 23(4), 317-335. http://dx.doi.org/10.1007/s10901-008-9120-2

Zheng, S., \& Zhang, W. (2007). The Spatial Interaction of Housing Cost and Commuting Cost: Evidence from Beijing Market. Progress in Geography, 2, 3542.

\section{Copyrights}

Copyright for this article is retained by the author(s), with first publication rights granted to the journal.

This is an open-access article distributed under the terms and conditions of the Creative Commons Attribution license (http://creativecommons.org/licenses/by/3.0/). 